\title{
Reproductive apparatus of the male giant hermit crab Petrochirus diogenes (Anomura, Diogenidae): morphology and phylogenetic implications
}

\author{
Raquel C. Buranelli, Fernando L. Mantelatto* \\ Laboratory of Bioecology and Crustacean Systematics (LBSC), Department of Biology, Faculty of Philosophy, \\ Sciences and Letters of Ribeirão Preto (FFCLRP), University of São Paulo (USP), Av. Bandeirantes, 3900, Ribeirão Preto, \\ São Paulo 14040-901, Brazil
}

\begin{abstract}
We describe the male reproductive apparatus of the giant hermit crab Petrochirus diogenes, with morphological and biometric analyses of the spermatophore, the gonopore and the ultrastructure of the spermatozoa. Specimens were collected from the southern coast of São Paulo, Brazil. Morphological analyses were done using stereoscopic, light, transmission and scanning electron microscopy. The reproductive system of this hermit crab is composed of elongate and lobular testes followed by vasa deferentia that connect to the exterior via gonopores. The gonopores are ovoid and surrounded by setae, and each gonopore is composed of a membranous operculum that forms a depression constituting the gonopore opening. The gonopore constitutes a unique structure among the Diogenidae due to its number of setae. The spermatophores are tripartite, composed of a sperm-containing ampulla, a peduncle and a proximal foot. The spermatozoon has 3 main regions (acrosomal vesicle, nucleus and cytoplasm). The structure of the spermatophore indicates that this species can be considered an exception within Diogenidae with regard to spermatophore morphology and can therefore be used for phylogenetic inferences.
\end{abstract}

KEY WORDS: Decapoda $\cdot$ Reproduction · Spermatophore $\cdot$ Spermiotaxonomy $\cdot$ Gonopore

Resale or republication not permitted without written consent of the publisher

\section{INTRODUCTION}

Comparisons of reproductive morphology are a taxonomic tool, providing key characters for species delimitation, solving taxonomic problems and establishing phylogenetic relationships between groups of crustaceans (Mantelatto et al. 2009a, Fantucci \& Mantelatto 2011). Recently, studies based on electron microscopy have intensified interest in morphological analyses of the reproductive structures of decapod crustaceans, especially in males (ManjónCabeza \& García-Raso 2000, Amadio \& Mantelatto 2009). Recent studies of the structure of spermatozoa and spermatophores among hermit crab families provide information on phylogenetic relationships (Mantelatto et al. 2009a).
The diogenid Petrochirus diogenes Linnaeus, 1758, one of the largest aquatic hermit crabs, is endemic to the western Atlantic and is distributed along the east coast of the USA, from North Carolina into the Gulf of Mexico, the Antilles, Venezuela, Suriname, Uruguay and Brazil (from Amapá in the north to Rio Grande do Sul in the south) (Coelho \& Ramos 1972, Williams 1984, Melo 1999).

Although our knowledge of the life cycle of Petrochirus diogenes is incomplete, some of the biological features of this species have been described in recent years, particularly in studies carried out in the southwestern Atlantic. Previous reports have described the larval development (Provenzano 1963, 1968), feeding and chewing structures (Caine 1975), behavior related to shell occupation (Kellogg 1977, Bertini 
1997, Bertini \& Fransozo 2000a), relative growth (Bertini \& Fransozo 1999a), population dynamics (Bertini \& Fransozo 2000b), spatial and seasonal distributions (Bertini \& Fransozo 1999b), reproductive period (Bertini \& Fransozo 2002) and population biology (Turra et al. 2002) of this species. Data on the morphology of the reproductive apparatus are still scant. To our knowledge, the only previous study on this topic is a description of spermatozoal ultrastructure by Brown (1966).

The male reproductive system in Decapoda is typically composed of a pair of testes connected to a pair of vasa deferentia (VD) that open to the exterior via gonopores located on the ventral side of the coxae of the fifth pair of pereiopods (Matthews 1953, McLaughlin 1983, Krol et al. 1992). The VD can be externally divided into proximal, median and distal regions (McLaughlin 1983, Amadio \& Mantelatto 2009). The testes and VD are generally located in the cephalothorax, but in some anomuran families, including hermit crabs, the gonads are situated in the pleon (McLaughlin 1983, Krol et al. 1992). The male reproductive apparatus of hermit crabs has a speciesspecific morphology and has recently been used in phylogenetic studies (Tudge 1997, Tirelli et al. 2006, 2008). Spermatozoa are bundled together with secretory materials in the VD and eventually form the spermatophores (Subramoniam 1991, 1993, Krol et al. 1992), a common means of spermatozoa transfer that has evolved among invertebrates (Tudge 1991, Subramoniam 1993). The production of these structures is habitat-related, and in marine species, the spermatophores appear to reduce spermatozoal loss (Subramoniam 1993). In addition, spermatophores provide an energy-rich substrate, allowing for spermatozoal storage over long periods (Subramoniam 1991, Scelzo et al. 2004, Mantelatto et al. 2009a).

Spermatophores play an important role in Crustacea because most crustacean spermatozoa, including those of all decapods, are aflagellate and nonmotile (Felgenhauer \& Abele 1991, Jamieson 1991), increasing the importance of a vehicle of transfer in the absence of an intromittent copulatory organ (Subramoniam 1993). Among Anomura, spermatophores are generally pedunculate (Subramoniam 1993, Tudge 1999b) and can be divided into 3 major regions: a sperm-filled ampulla, a stalk of variable length and a sticky foot or pedestal that affixes the spermatophore onto the female (Tudge 1991, 1999a, Subramoniam 1993). Spermatophores in anomurans display species-specific morphology in the shape of the ampulla and the length of the peduncle (Subramoniam 1984). In Diogenidae, spermatophores gen- erally display long, thin stalks and small, spherical ampullae (Tudge 1991).

Spermatozoa morphology also varies among crustaceans, and it is difficult to identify features that characterize the entire class (Jamieson 1991, Tudge 2009). However, ultrastructural analyses have been useful in elucidating phylogenetic relationships, principally in Decapoda (Tudge 1992, 1997, 2009, Jamieson 1994). In decapods, the spermatozoon is composed of a large acrosomal vesicle with multiple concentric zones, a basal nucleus and an intermediate cytoplasm with organelles and a variable number of arms or spikes (Tudge 1992, 2009). In Anomura, the acrosomal vesicle is divided into concentric layers, delimited by an electron-dense operculum and penetrated by a perforatorial chamber, and there are 3 microtubular arms emerging from the cytoplasm or nucleus (Jamieson 1991, Tirelli et al. 2008). The spermatozoa of Diogenidae, though, are not a clear phylogenetic marker at the family level, as they share characteristics with the spermatozoa of some members of the families Paguridae and Coenobitidae (Tudge 1992).

The present study describes the male reproductive apparatus of the giant hermit crab Petrochirus diogenes and morphological and biometric analyses of the spermatophore, gonopore and spermatozoal ultrastructure, to provide information on phylogeny.

\section{MATERIALS AND METHODS}

Specimens of Petrochirus diogenes were collected using a shrimp fishing boat equipped with doublerig trawling nets in the Enseada de Ubatuba region $\left(23^{\circ} 25^{\prime} 06^{\prime \prime}\right.$ to $23^{\circ} 27^{\prime} 42^{\prime \prime} \mathrm{S}$ and $45^{\circ} 05^{\prime} 00^{\prime \prime}$ to $\left.45^{\circ} 02^{\prime} 48^{\prime \prime} \mathrm{W}\right)$, Ubatuba, São Paulo, southeastern Brazil. The live hermit crabs were maintained in the laboratory until the analysis was conducted. We selected 15 males covering the widest possible range of sizes. All procedures followed the protocols described by Scelzo et al. $(2004,2010)$, Amadio \& Mantelatto (2009) and Mantelatto et al. (2009a).

Each individual was anesthetized by chilling, its shield length (SL) was measured (from the tip of the rostrum to the $\mathrm{V}$-shaped groove at the posterior edge) with a caliper rule $(0.1 \mathrm{~mm})$, and its wet weight was measured using an electronic balance $(0.01 \mathrm{~g})$. Also, the largest diameter of both gonopores of each animal was measured using a stereomicroscope with a camera lucida. Gonopore samples for SEM analysis were isolated from the crab by removing a section (coxae) of the fifth legs, containing the gonopores. 
Each individual was dissected in the dorsal position, and an incision was made in the cuticle of the pleon, exposing the hepatopancreas and the reproductive system. Spermatophores from each region of the VD were analyzed using light microscopy, and photos were obtained; 10 spermatophores from the distal portion of the VD of each animal were used for biometric analysis, and the following measures were taken using a light microscope: ampulla length (AL), peduncle or stalk length (PL), total length of the spermatophore (TL), ampulla width (AW) and peduncle width (PW) (Fig. 1). Testes, VD and spermatophores were preserved in $80 \%$ ethanol.

Data (including dry weight, shield length, gonopore diameters and spermatophore measures) were analyzed using Sigma Stat for Windows, v. 2.03, with $\alpha=0.05$ for all tests. The data were tested for normality, and a Pearson's correlation was performed to examine the relationship between shield length and spermatophore biometrics, which were normally distributed. Spearman's correlations were used to analyze the relationships between shield length and each of dry weight and gonopore diameter, which were non-normally distributed.

Details of gonopore and spermatophore morphology were obtained using scanning electron microscopy (SEM), and spermatozoa were analyzed using transmission electron microscopy (TEM). For SEM analysis, samples were fixed in 3\% glutaraldehyde

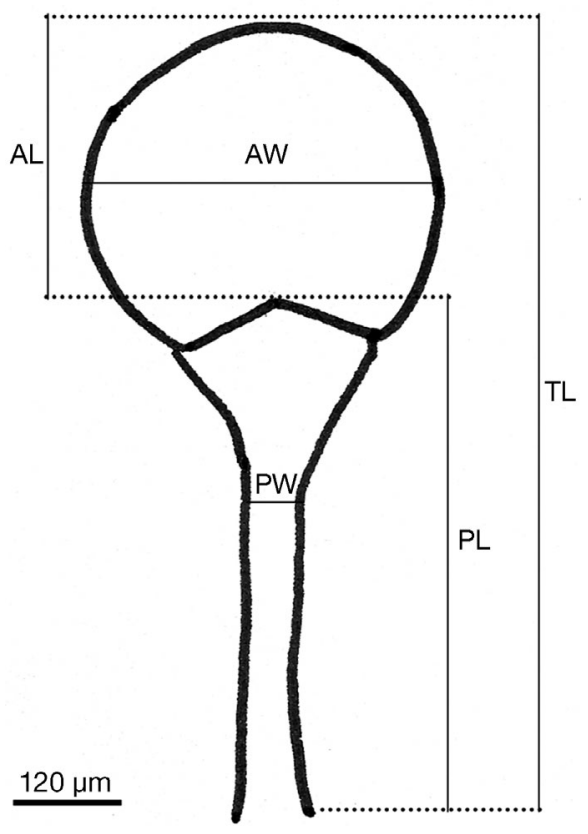

Fig. 1. Petrochirus diogenes. Drawing of a spermatophore showing the measurements taken: (TL) spermatophore total length, (PL) peduncle length, (PW) peduncle width, (AW) ampulla width, (AL) ampulla length
(5 $\mathrm{d}$ for gonopore samples; $2 \mathrm{~h}$ for spermatophores), transferred to phosphate saline buffer and post-fixed for $2 \mathrm{~h}$ in 1 to $2 \% \mathrm{OsO}_{4}$ in buffer solution, dehydrated in ethanol $(30 \%, 50 \%, 70 \%, 80 \%, 90 \%$ and 3 steps in $100 \%$ for $30 \mathrm{~min}$ each) and critical-point dried using liquid $\mathrm{CO}_{2}$. Samples were then placed on SEM stubs, sputter-coated with gold, then observed and photographed in a scanning electron microscope (JEOL JSM5410; JEOL JS5200). TEM samples were prepared using procedures similar to those applied to the SEM samples. Following dehydration, the material was embedded in Epon-Araldite resin, cut into thin sections on an ultramicrotome Leica Ultracut $\mathrm{S}$ with a diamond blade and transferred to copper grids. Samples were then stained with lead citrate and uranyl acetate and observed and photographed in a transmission electron microscope (JEOL JEM100CX2).

Voucher specimens were deposited in the Crustacean Collection of the Biology Department (CCDB) of the Faculty of Philosophy, Sciences and Letters of Ribeirão Preto (FFCLRP) at the University of São Paulo, Brazil (catalogue numbers CCDB 3110 to 3116 and CCDB 3118).

\section{RESULTS}

A total of 15 adult specimens were analyzed, and the specimens presented SL values ranging from 12.46 to $31.62 \mathrm{~mm}$ and averaging $25.31 \pm 5.54 \mathrm{~mm}$ and wet weights ranging from 22.35 to $414.29 \mathrm{~g}$ and averaging $247.35 \pm 38.98 \mathrm{~g}$ (Table 1 ). These measurements were positively and significantly correlated with the size (SL) of the animals ( $\mathrm{rs}=0.933, \mathrm{p}<$ 0.001).

\section{Reproductive system}

The reproductive system is composed of paired testes followed by a pair of VD (Fig. 2) that communicate to the exterior via gonopores located on the bases of the coxae of the fifth pair of pereiopods. The testes and VD are located dorsally in the pleon, in a central position, and they are adjacent to the hepatopancreas. The testes are white, lobular and elongated on the antero-posterior axis. The VD are also white and consist of coiled tubular ducts that can be divided into 3 different regions (proximal, median and distal) according to their external morphology. The proximal region is near the testes and is coiled, the median region is also coiled but less so than the 
Table 1. Petrochirus diogenes. Body dimensions and spermatophore measurements $(\mathrm{n}=15)$. SL: shield length; W: wet weight; AL: ampulla length; PL: peduncle length; TL: total length; AW: ampulla width; PW: peduncle width

\begin{tabular}{|lccccc|}
\hline & Mean \pm SD & Minimum & Maximum & \multicolumn{2}{c|}{ Correlation to SL } \\
& & & & $\mathrm{r}$ & $\mathrm{p}$ \\
\hline SL $(\mathrm{mm})$ & $25.31 \pm 5.54$ & 12.46 & 31.62 & - & - \\
W $(\mathrm{g})$ & $247.35 \pm 138.98$ & 22.35 & 414.29 & - & - \\
AL $(\mu \mathrm{m})$ & $263.53 \pm 65.75$ & 120 & 420 & 0.745 & 0.001 \\
PL $(\mu \mathrm{m})$ & $524.9 \pm 154.9$ & 170 & 820 & 0.709 & 0.003 \\
TL $(\mu \mathrm{m})$ & $728.3 \pm 201.3$ & 270 & 1180 & 0.736 & 0.002 \\
AW $(\mu \mathrm{m})$ & $263.4 \pm 65.4$ & 110 & 400 & 0.806 & $<0.001$ \\
PW $(\mu \mathrm{m})$ & $48.5 \pm 16.07$ & 20 & 110 & 0.483 & 0.068 \\
\hline
\end{tabular}

proximal region, and the distal region is straight and ends in a gonopore near the anterior part of the pleon (Fig. 2).

\section{Gonopores}

The gonopores are oval, completely surrounded and covered by plumose and simple setae (Fig. 3A,B), and have a calcified gonopore cover (Fig. 3C). Each gonopore presents a probably calcified operculum (gonopore cover), totally covered by plumose setae (Ps) (according to Watling 1989) that originate in the anterior region and end in a depression, which constitutes the gonopore opening (Fig. 3B,C). In the posterior region of the gonopore, there is a group of simple setae (Ss) (according to Watling 1989) bordering the opening (Fig. 3B-E).

The 2 gonopores occupy a significant portion of the coxae of the fifth pair of pereiopods. The largest diameter of the gonopores ranged from 1.39 to $5.04 \mathrm{~mm}$, averaging $3.61 \pm 0.79 \mathrm{~mm}(\mathrm{n}=15)$ for crabs measuring 12.46 to $31.62 \mathrm{~mm}$ SL. The correlation between the largest diameter of the gonopores and SL was positive ( $\mathrm{rs}=0.908, \mathrm{p}<0.001)$.

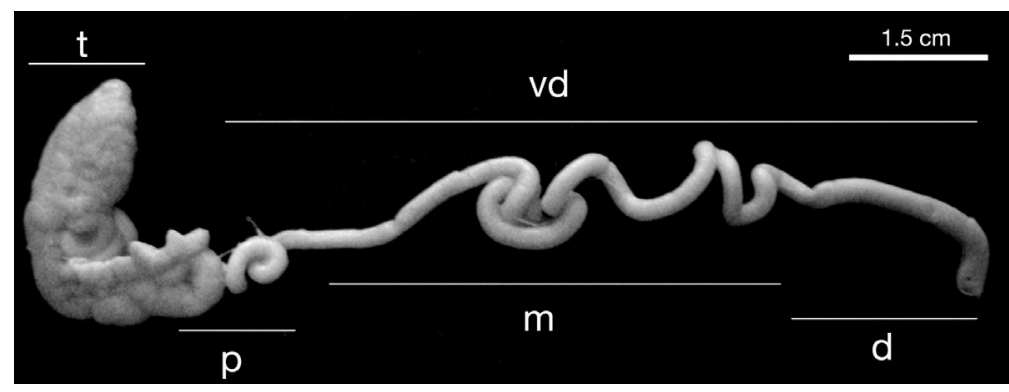

Fig. 2. Petrochirus diogenes. Reproductive system of the adult male, with (t) testis and the $(\mathrm{p})$ proximal, $(\mathrm{m})$ median and $(\mathrm{d})$ distal regions of the $(\mathrm{vd})$ vas deferens

\section{Spermatophores}

The spermatophore is pedunculate and is divided into 3 major regions: a distal spherical sperm-filled ampulla, a thin stalk and a proximal foot (Fig. 4A,B). The presence of mucus surrounding the spermatophores interfered with the SEM observations of the foot and the end of the stalk (Fig. 4C). The ampulla is larger than the stalk, which has a small projection where it joins the ampulla (Fig. 4A). The ampulla is nearly spherical (Fig. 4A,B), with a suboval shape laterally, and consists of 2 valves joined along their lateral edges by a low lateral ridge (Fig. 4D). The external surface of the ampulla is irregular, with small depressions likely formed either by the tight packaging of spermatozoa within the ampulla or by the process of dehydration for SEM, or both (Fig. 4D). The lateral ridge is externally formed by a thickening in the wall of the ampulla where the 2 valves meet, through which the valves likely release spermatozoa (Fig. 4D).

We observed no significant morphological differences between the spermatophores produced in different regions along the VD. Spermatophores from the proximal region had slightly flatter spherical ampullae and shorter, thicker stalks. Spermatophores from the median region had stalks that were intermediate in length and thickness and spherical ampullae indistinguishable from those on spermatophores from the distal region of the VD.

\section{Spermatozoon}

The spermatozoon has 3 main regions: an ovoid acrosomal vesicle, a basal nucleus and an amorphous intermediate cytoplasm (Fig. 5A,B) with 3 arm-shaped extensions (Fig. 5C). The acrosomal vesicle is divided into an inner acrosome zone, an acrosome ray zone and an outer acrosome zone (Figs. 5A,B,D). The inner acrosome zone constitutes the central column of the spermatozoon and is the less electron-dense layer of the acrosomal vesicle (Fig. 5A,B,D). The outer acrosome zone surrounds the acrosomal vesicle except for the operculum (Fig. 5A,B). The acrosomal vesicle has an electron-dense operculum at its apex, followed by a granular subopercular zone, which extends posteriorly into the inner acrosome zone 

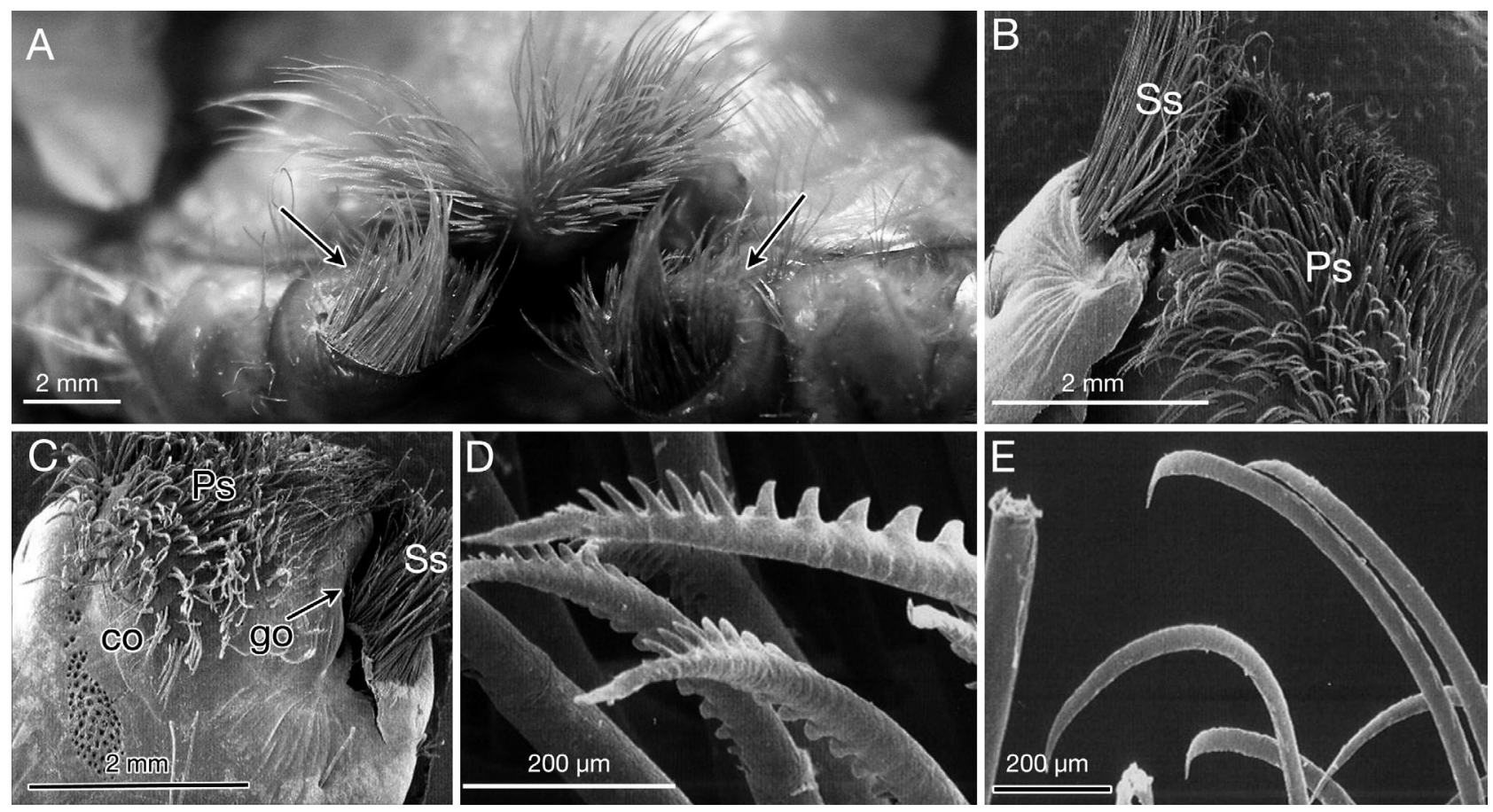

Fig. 3. Petrochirus diogenes. Gonopore morphology. (A) Detail of the fifth pair of pereopods; arrows indicate the gonopores. Scanning electronic micrographs: (B) Gonopore completely covered by (Ps) plumose and (Ss) simple setae. (C) Gonopore with (co) the calcified gonopore cover with (Ps) plumose setae, (go) the depression that constitutes the gonopore opening and

the group of $(\mathrm{Ss})$ simple setae bordering this opening. (D) Detail of the plumose setae. (E) Detail of the simple setae

(Fig. 5A,B). The vesicle is also penetrated at its base into its center by a cylindrical perforatorial chamber, which extends along the apical-basal axis (Fig. 5A-C) and presents microvillar projections on its wall (Fig. 5B,D). The nucleus is located at the base of the spermatozoon and consists of an amorphous structure with a granular aspect, and its border to the cytoplasm is not well defined, due to the absence of a membrane (Fig. 5A,B). The cytoplasm, located in the base of the sperm cell, is continuous with the perforatorial chamber (Fig. 5A,B,D) and contains organelles such as mitochondria (Fig. 5D).

\section{DISCUSSION}

\section{Reproductive system}

The male reproductive system is located dorsally in the pleon, as in other Anomura (McLaughlin 1983, Krol et al. 1992), whereas in other decapod crustaceans, the reproductive organs are located in the cephalothorax (McLaughlin 1983, Krol et al. 1992, Amadio \& Mantelatto 2009). The basic composition of the reproductive system, including a pair of testes connected to a pair of VD that open to the exterior via gonopores, is similar to that seen in other decapods
(Matthews 1953, McLaughlin 1983, Krol et al. 1992, Amadio \& Mantelatto 2009), as is the apparent division of the VD into 3 different regions (McLaughlin 1983, Amadio \& Mantelatto 2009). The testes are elongated and lobular as in other hermit crabs, such as Diogenes pugilator Roux, 1828 (Manjón-Cabeza \& García-Raso 2000), Calcinus tubularis L., 1767 (Tirelli et al. 2006), and Calcinus tibicen Herbst, 1791 (Amadio \& Mantelatto 2009).

Morphological and histological features of the VD are associated with spermatophore development in that spermatophore formation is determined by the secretory, muscular and glandular activities of the VD (Mouchet 1931). The shape of the spermatophore is also related to and influenced by the shape of the VD (Mouchet 1931). A detailed understanding of the morphology and histology of the VD is therefore important, and histological analyses of this structure are needed to obtain a better comprehension of the reproductive system.

\section{Gonopores}

The male gonopores of Petrochirus diogenes are ovoid in shape, the same pattern described in other species of Diogenidae, such as Calcinus tibicen 

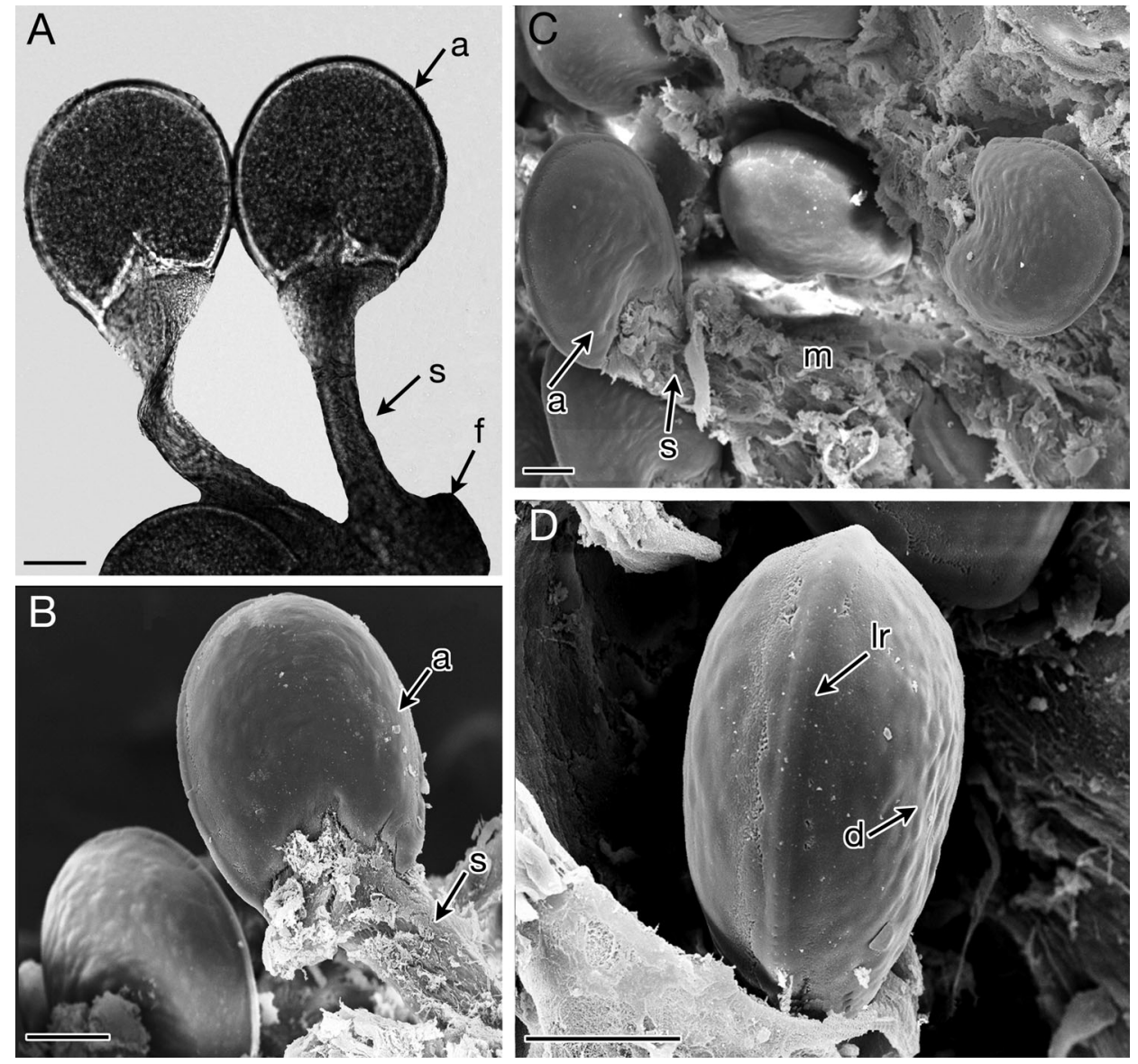

Fig. 4. Petrochirus diogenes. Spermatophore morphology. (A) General morphology, including (a) the ampulla, (s) the stalk and (f) the proximal foot. Scanning electronic micrographs: (B) General morphology of the spermatophore, including (a) the ampulla and (s) the stalk. (C) Mass of spermatophores with (a) ampulla, (s) stalk and (m) mucous surrounding them. (D) Detail of the ampulla, showing the (lr) lateral ridge and (d) depressions in the wall. Scale bars $=100 \mu \mathrm{m}$

(Amadio \& Mantelatto 2009), Isocheles sawayai Forest \& Saint Laurent, 1968 (Mantelatto et al. 2009b), and Loxopagurus loxochelis Moreira, 1901 (Scelzo et al. 2004). However, the gonopores of $P$. diogenes differ significantly from those of other species with respect to the number of associated setae. Whereas the gonopores of $P$. diogenes are completely surrounded by setae, the gonopores of some species, such as Calcinus tibicen (Amadio \& Mantelatto 2009) and Clibanarius sclopetarius Herbst, 1796 (Santos \& Mantelatto 2011), exhibit few or no setae. Other species, such as I. sawayai (Mantelatto et al. 2009b), L. loxochelis (Scelzo et al. 2004), Clibanarius erythropus Latreille, 1818 (Tirelli et al. 2007), and Diogenes pugilator (Manjón-Cabeza \& García-Raso 2000), exhibit an intermediate number of gonopore setae, but these are still far fewer than in $P$. diogenes.

During reproduction, the setae surrounding the gonopore might play an important role as sensors of the female cephalothorax and genital openings in addition to facilitating the transfer of spermatophores to females during copulation (Manjón-Cabeza \& GarcíaRaso 2000, Tirelli et al. 2007), thereby increasing transfer efficiency and reproductive success. The presence of transfer structures (other than setae) in Diogenidae is known only in the genera Paguristes Dana, 1851, and Pseudopaguristes McLaughlin, 2002, in which the first and second pairs of abdominal pleopods in the male are modified as gonopods that act as transfer agents (Tudge \& Lemaitre 2004). Some other families, including Coenobitidae and Paguridae, have specialized spermatozoa transfer structures called sexual tubes, which consist of prolongations of either the VD or the male gonopores (Tudge \& Lemaitre 2004), but these are also not found in Petrochirus diogenes.

There is limited information in the literature about how the spermatophores are transferred to the female. We only know that in the superfamily Paguroidea, spermatophores are placed externally on the exoskeleton or in the surface of the gastropod shell 

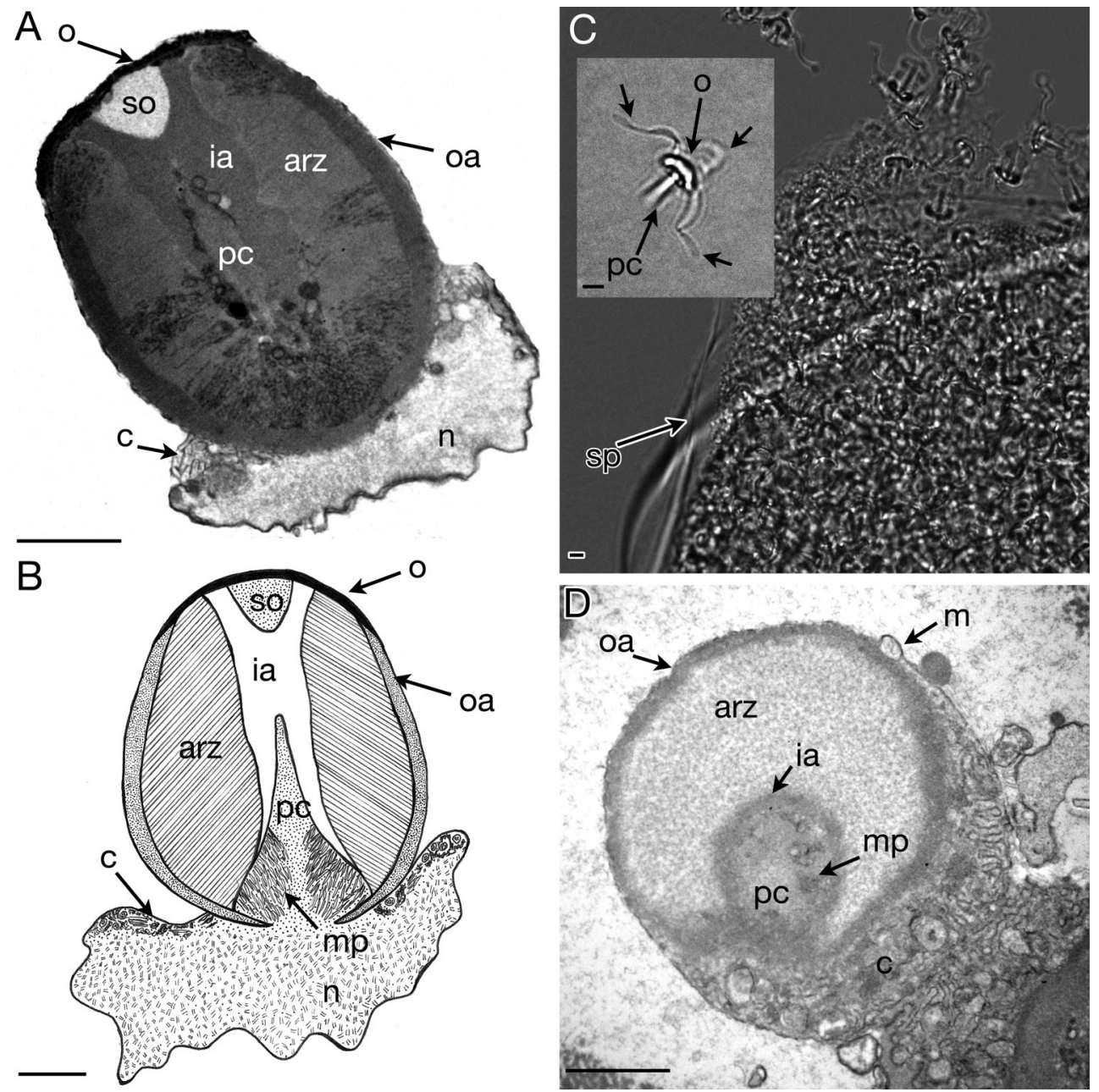

Fig. 5. Petrochirus diogenes. Spermatozoon morphology. (A) Tangential section of the spermatozoon, showing the ovoid acrosomal vesicle, (n) the nucleus and (c) the cytoplasm (scanning electron microscopy). (B) Spermatozoon illustration showing $(\mathrm{mp})$ microvillar projections of the perforatorial chamber. (C) Spermatophore releasing the mass of spermatozoa; on the detail, arrows indicate the 3 arms (light microscopy). (D) Transversal section of the spermatozoon, showing (m) mitochondria in the cytoplasm. ia: inner acrosome zone; oa: outer acrosome zone; arz: acrosome ray zone; o: operculum; so: subopercular zone; pc: perforatorial chamber. Scale bars $=2 \mu \mathrm{m}$

inhabited by the female (Matthews 1953, Tudge 1991, Hess \& Bauer 2002).

The positive correlation between the SL measurements and gonopore diameter indicates that the size of the gonopores is directly proportional to the size of the hermit crab, as reported for other diogenid species (Amadio \& Mantelatto 2009, Mantelatto et al. 2009b, Santos \& Mantelatto 2011). This pattern means that an intimate relationship during ontogeny occurs between hermit crab size and reproductive body dimensions.

\section{Spermatophores}

Spermatophore morphology has now been described for 25 species in 11 genera of diogenid hermit crabs, which represent $6 \%$ and $55 \%$ of all known species and genera, respectively. The present study provides the first detailed description of spermatophore morphology and morphometry for hermit crabs of the genus Petrochirus.

The spermatophores of Petrochirus diogenes are morphologically similar to those previously described in several other diogenid species, including Calcinus minutus Buitendijk, 1937, Calcinus latens Randall, 1839, Clibanarius corallinus H. Milne Edwards, 1848, and Clibanarius virescens Krauss, 1843. The spermatophores of these species consist of a small and spherical ampulla and a long, thin stalk (Tudge 1991).

The external morphology of the lateral ridge in Petrochirus diogenes is also similar to that observed in other species of Diogenidae, including Calcinus 
tibicen (Amadio \& Mantelatto 2009), C. tubularis (Tirelli et al. 2006), Isocheles sawayai (Mantelatto et al. 2009a) and Diogenes pugilator (Tirelli et al. 2008). In these species, the lateral ridge consists of a thickening of the wall of the ampulla at the border along which the 2 valves are joined.

Despite these similarities, the analyses using light and electron microscopy in the current study revealed that the spermatophore of Petrochirus diogenes presents an exception among Diogenidae. Although it has a spherical ampulla and a thin stalk, the spermatophore in this species presents a relatively large ampulla in relation to the length of the stalk. Similar proportions are seen in the spermatophores of Calcinus tibicen (Amadio \& Mantelatto 2009) and C. minutus (Tudge 1991). This similarity suggests that this particular spermatophore morphology is a shared trait in these species, a possibility that is corroborated by a recent molecular phylogeny (Mantelatto et al. 2009b).

Other Diogenidae, such as Diogenes gardineri Alcock, 1905, and Isocheles sawayai, also show spermatophores with large ampullae relative to the stalk (Tudge 1991, Mantelatto et al. 2009a). However, in these species, this proportion is seen in width measurements, not length, as the stalk of the spermatophore is very long in these species, as discussed below.

Although continuous characters are generally not used for phylogenetic analyses of morphological data, new methods have recently incorporated algorithms for their analysis (Goloboff et al. 2006). However, some continuous characters, such as spermatophore measurements, should not be used to infer relationships or, as proposed by Scelzo et al. (2004), as a criterion to characterize and distinguish species, because the dimensions are strongly associated with the individual size and cannot be used alone in phylogenetic comparisons (Amadio \& Mantelatto 2009, Santos \& Mantelatto 2011). Nonetheless, proportions between spermatophore regions can indicate shape (such as an ovoid or cylindrical ampulla or an ampulla much bigger than the stalk) and can be used to infer phylogenetic relationships.
The measurements of the spermatophore of Petrochirus diogenes confirm that the ampulla is relatively large in relation to stalk length. The mean AW is 5.4fold greater than PW in this species, and the mean PL is less than twice AL (Table 2). Similar proportions between the ampulla and the stalk are also found in other species of Diogenidae, such as Calcinus tibicen (Table 2) (Amadio \& Mantelatto 2009). Some diogenid species show different spermatophore proportions, however. In Isocheles sawayai, the relationship between AW and PW is similar to that found in P. diogenes, but PL is much larger than AL (Mantelatto et al. 2009a). In Loxopagurus loxochelis, also a member of Diogenidae, the difference between AW and PW is not as large, and PL is more than twice AL (Scelzo et al. 2004).

Analysis of the male reproductive apparatus in combination with molecular, behavioral and population studies enhances our understanding of the life history of this species and provides information on phylogenetic relationships. In this vein, considering the phylogenetic tree in Fig. 6, based on molecular data, it is apparent that Calcinus tibicen is phylogenetically closer to Petrochirus diogenes than to Isocheles sawayai or Loxopagurus loxochelis. This proximity can be corroborated by spermatophore morphology, as C. tibicen exhibits spermatophore morphology that is more similar to that of $P$. diogenes than to the spermatophore morphologies of the other 2 species, as described above.

In contrast, diogenid genera such as Dardanus Pauls̀on, 1875, and Clibanarius Dana, 1852, showed proximity to Petrochirus diogenes in the phylogenetic tree, but their spermatophore morphology presents different features compared to those of Calcinus Dana, 1851. The genus Dardanus has few species with described spermatophores, but Dardanus megistos Herbst, 1804, has a spermatophore with a thick, short stalk and a small, ovoid ampulla (Tudge 1991), which differs from the spermatophores of $P$. diogenes. The genus Clibanarius, besides its proximity to $P$. diogenes, has species with 2 types of spermatophores. Species such as Clibanarius sclopetarius

Table 2. Comparisons of the spermatophore measurements of some representatives of the family Diogenidae. AW: ampulla width; PW: peduncle width; PL: peduncle length; AL: ampulla length; $\mathrm{n}$ : sample size

\begin{tabular}{|lcccrl|}
\hline Species & AW/PW & PL $(\mu \mathrm{m})$ & AL $(\mu \mathrm{m})$ & $\mathrm{n}$ & Source \\
\hline Petrochirus diogenes & 5.43 & $524.9 \pm 154.9$ & $263.53 \pm 65.75$ & 15 & Present study (Table 1) \\
Calcinus tibicen & 3.37 & $130 \pm 45$ & $89.8 \pm 17.8$ & 30 & Amadio \& Mantelatto (2009) \\
Isocheles sawayai & 3.63 & $498 \pm 280$ & $102 \pm 33$ & 70 & Mantelatto et al. (2009a) \\
Loxopagurus loxochelis & 2.22 & $278 \pm 102$ & $116 \pm 23$ & 298 & Scelzo et al. (2004) \\
\hline
\end{tabular}


and C. vittatus Bosc, 1802, show non-tripartite spermatophores, without stalks or feet, but the ampulla morphology follows that described for Diogenidae (Hess \& Bauer 2002, Santos \& Mantelatto 2011). Other species, such as $C$. erythropus and $C$. corallinus, show tripartite spermatophores with small, spherical ampullae and thin, long stalks (Tudge 1991), so the non-tripartite pattern can be considered as a secondary loss in this genus (Santos \& Mantelatto 2011). Species from the family Coenobitidae, represented by Coenobita compressus $\mathrm{H}$. Milne Edwards, 1837, in the phylogenetic tree, also have different spermatophores, with large spherical ampullae and short thick stalks, showing a robust appearance (Tudge 1991).

Overall, despite these proportional morphometric differences among the spermatophores in the family Diogenidae, these structures are generally pedunculated, with the size of the ampulla varying in relation to the size of the stalk. This morphology allows a finer

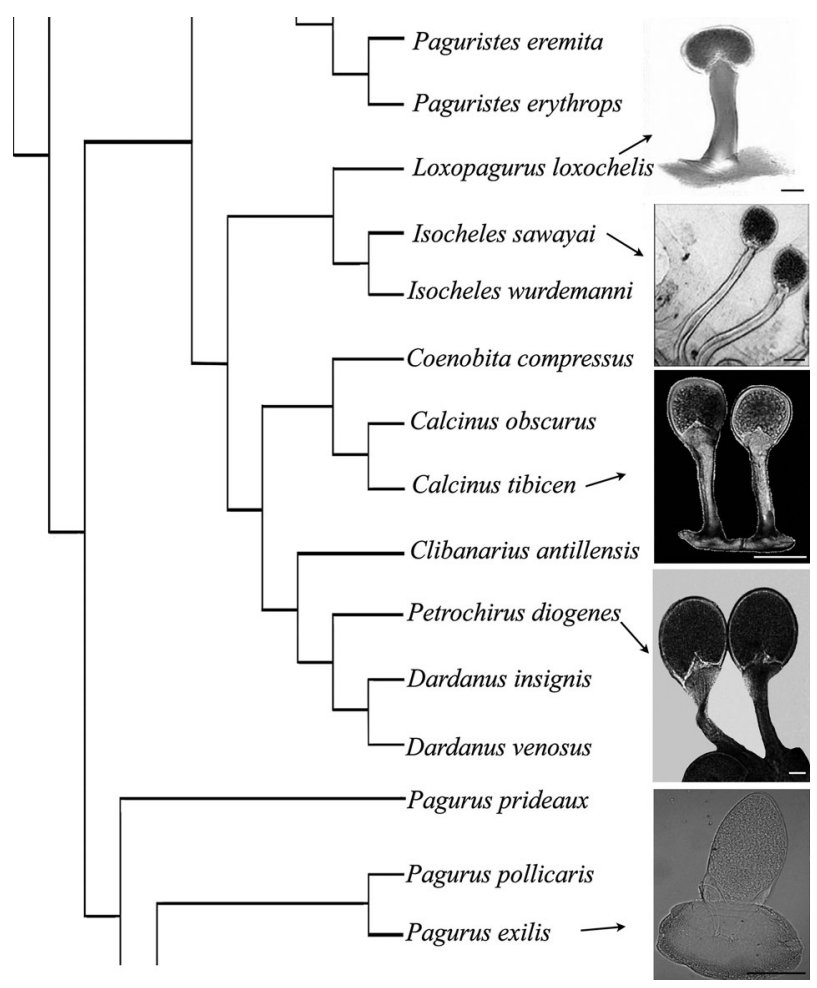

Fig. 6. Part of a phylogenetic tree based on molecular characters (modified from Mantelatto et al. 2009b) with the spermatophore morphology of representatives of the family Diogenidae (Loxopagurus loxochelis [modified from Scelzo et al. 2004], Isocheles sawayai [modified from Mantelatto et al. 2009a], Calcinus tibicen [modified from Amadio \& Mantelatto 2009] and Petrochirus diogenes [present study]) and Paguridae (Pagurus exilis [modified from Scelzo et al. 2010]). Scale bars $=70 \mu \mathrm{m}$ taxonomic resolution of the species, in addition to differentiating the spermatophores of these species from those of species in other families, such as Paguridae (Fig. 6).

The positive correlations between SL and weight, and between SL and spermatophore measurements (AL, PL, TL, AW and PW) indicate that the size of the spermatophores is directly proportional to the size and weight of the animal. This pattern has also been found in other species in Diogenidae, including Calcinus tibicen (Amadio \& Mantelatto 2009) and Clibanarius sclopetarius (Santos \& Mantelatto 2011).

\section{Spermatozoon}

The characteristics of the spermatozoon of Petrochirus diogenes found in the present study are similar to those described by Brown (1966), especially with respect to the tri-radial shape of this structure, its immobility and the presence of a multilayered acrosomal vesicle with an apical operculum. Brown (1966) found an acrosomal vesicle comprising 3 layers: an outer dense layer with an inner tubular part surrounded by an amorphous one, a middle microtubular layer that he called the bulk of the acrosomal vesicle and a dense inner layer that extends from the apex into the proximal end. In sequence, these layers probably correspond to what we call here the acrosome ray zone surrounded by the outer acrosome zone, the inner acrosome zone as the 'bulk of the acrosomal vesicle' and the perforatorial chamber as the dense inner layer. Nevertheless, Brown (1966) did not mention the presence of a subopercular zone and found no mitochondrion.

The spermatozoon of Petrochirus diogenes is generally similar to those observed in other species of Decapoda in possessing an acrosomal vesicle, a basal nucleus and an intermediate cytoplasm with organelles and arms (Tudge 1992, 2009). The acrosomal vesicle with multiple layers delimited by an electrondense operculum, the perforatorial chamber penetrating this acrosomal vesicle and the 3 microtubular arms are all characteristics found in spermatozoa among anomurans (Jamieson 1991, Tirelli et al. 2008).

These 3 characteristics mentioned above are also found in the spermatozoa of other Diogenidae, such as Strigopagurus boreonotus Forest, 1995 (Tudge 1996), Diogenes pugilator (Tirelli et al. 2008), Calcinus tibicen (Amadio \& Mantelatto 2009) and Clibanarius sclopetarius (Santos \& Mantelatto 2011). The acrosomal vesicles of diogenid species range from ovoid, in Dardanus crassimanus H. Milne Edwards, 
1836 (Tudge 1992), to spherical, in C. tibicen (Amadio \& Mantelatto 2009), or almost spherical, such as those of Clibanarius corallinus (Tudge 1992). All diogenid species with described spermatozoa show a conical operculum at the anterior pole of the spermatozoon, sometimes followed by a subopercular zone, as in Diogenes custos Fabricius, 1798 (Tudge 1992). The perforatorial chamber penetrating the acrosomal vesicle can be found in all diogenids, and its extension varies among species. It extends anteriorly from for one-third of the length of the acrosomal vesicle, as in D. crassimanus (Tudge 1992), up to almost the entire length of the vesicle, as in C. tibicen (Amadio \& Mantelatto 2009).

Except for the species of the genus Clibanarius, all diogenid species present spermatozoa with a 3layered acrosomal vesicle, showing an inner and outer acrosome zone and an acrosome ray zone (Tudge 1992, 1995, Tirelli et al. 2008, Amadio \& Mantelatto 2009). Also, the genus Clibanarius shows a spermatozoon with a perforatorial chamber, divided into a posterior perforatorial bulb and an anterior perforatorial projection (Jamieson 1991, Tudge 1992, Tirelli et al. 2007, Santos \& Mantelatto 2011).

This range of features suggests that there are no family-specific characteristics in the spermatozoa of this family. Moreover, some species in this family also show spermatozoa with characteristics found in the spermatozoa in the families Paguridae and Coenobitidae, including some representatives of the genera Clibanarius and Diogenes Dhillon, 1968, respectively (Tudge 1992, 1995).

Ultrastructural analyses of sperm morphology in Diogenidae are limited in terms of species diversity because most of these analyses have focused on the description of spermatozoa in only a few genera. Additional studies should therefore be done, including the analysis of the male reproductive system of other species of hermit crabs. This would improve our understanding of reproduction in these species and provide useful information on phylogenetic relationships.

Acknowledgements. The present study was part of a bachelor's thesis by R.C.B. supported by a Scientific Initiation Fellowship from the Conselho Nacional de Desenvolvimento Científico e Tecnológico (CNPq Proc. 138475/2009-1 and 2010.1.1389.59.0) and the Fundação de Amparo à Pesquisa do Estado de São Paulo (FAPESP) (Proc. 2010/11988-9). F.L.M. is grateful to CNPq (Proc. 301359/2007-5; 302748/2010-5) and FAPESP (Proc. 2010/50188-8) for research fellowships. A PhD Fellowship has been awarded to R.C.B. by FAPESP (Proc. 2012/06299-5). Samples were prepared for electron microscopy by M. Dolores Seabra Ferreira and J. Maulin at the Laboratory of Electron Microscopy of the Faculty of Medicine of Ribeirão Preto/USP and by C. Aparecida Rodrigues at the Laboratory of Electron Microscopy of the Faculty of Agriculture and Veterinary Sciences of Universidade Estadual Paulista 'Júlio de Mesquita Filho.' Á. da Silva Costa and D. Rosa helped with field sampling, C. Tudge helped with literature, M. Bitondi, F. Zara, M. Terossi and E. Almeida made helpful suggestions during R.C.B.'s thesis defense, and the Instituto Oceanográfico/USP (IO - Ubatuba/SP/Brazil) provided space and infrastructure. We also thank the anonymous reviewers for their suggestions. All experiments complied with state and federal laws of Brazil.

\section{LITERATURE CITED}

Amadio LM, Mantelatto FM (2009) Description of the male reproductive system of the hermit crab Calcinus tibicen (Decapoda: Anomura: Diogenidae). J Crustac Biol 29: 466-475

Bertini G (1997) Bioecologia de Petrochirus diogenes (Linnaeus, 1758) (Crustacea, Anomura Diogenidae) na Região de Ubatuba, São Paulo. MSc thesis, Universidade Estadual Paulista, Botucatu

Bertini G, Fransozo A (1999a) Relative growth of Petrochirus diogenes (Linnaeus, 1758) (Crustacea, Anomura, Diogenidae) in the Ubatuba Region, São Paulo, Brazil. Rev Bras Biol 59:617-625

Bertini G, Fransozo A (1999b) Spatial and seasonal distribution of Petrochirus diogenes (Anomura, Diogenidae) in the Ubatuba bay, São Paulo, Brazil. Iheringia Ser Zool 86: 145-150

Bertini G, Fransozo A (2000a) Patterns of shell utilization in Petrochirus diogenes (Decapoda, Anomura, Diogenidae) in the Ubatuba Region, São Paulo, Brazil. J Crustac Biol 20:468-473

Bertini G, Fransozo A (2000b) Population dynamics of Petrochirus diogenes (Crustacea, Anomura, Diogenidae) in the Ubatuba region, São Paulo, Brazil. In: Vaupel Klein JC, Schram FR (eds) The biodiversity crisis and crustacea. Proc 4th Int Crustac Congr, Balkema, Rotterdam, p 331-342

Bertini G, Fransozo A (2002) Breeding season of the hermit crab Petrochirus diogenes (Anomura: Diogenidae) in the north coast of São Paulo state, Brazil. In: Escobar-Briones E, Alvarez F (eds) Modern approaches to the study of crustacea. Kluwer Academic/Plenum Press, New York, NY, p 145-150

Brown GG (1966) Ultrastructural studies on crustacean spermatozoa and fertilization. PhD dissertation, University of Miami

$>$ Caine EA (1975) Feeding and masticatory structures of selected Anomura (Crustacea). J Exp Mar Biol Ecol 18: 277-301

Coelho PA, Ramos MA (1972) A constituição e a distribuição da fauna de Decapodos do litoral leste da América do Sul entre as latitudes de $5^{\circ} \mathrm{N}$ e $39^{\circ} \mathrm{S}$. Trab Oceanogr Univ Fed de Pernambuco 13:133-236

Fantucci MZ, Mantelatto FL (2011) Male reproductive apparatus and spermatophore morphology of the hermit crabs Pagurus brevidactylus and P. criniticornis (Anomura, Paguridae). J Morphol 272:1271-1280

Felgenhauer BE, Abele LG (1991) Morphological diversity of decapod spermatozoa. In: Bauer RT, Martin JW (eds) Crustacean sexual biology. Columbia University Press, New York, NY, p 322-341

Goloboff PA, Mattoni CI, Quinteros AS (2006) Continuous 
characters analyzed as such. Cladistics 22:589-601

Hess GS, Bauer RT (2002) Spermatophore transfer in the hermit crab Clibanarius vittatus (Crustacea, Anomura, Diogenidae). J Morphol 253:166-175

Jamieson BGM (1991) Ultrastructure and phylogeny of crustacean spermatozoa. Mem Queensl Mus 31:109-142

> Jamieson BGM (1994) Phylogeny of the Brachyura with particular reference to the Podotremata: evidence from a review of spermatozoal ultrastructure (Crustacea, Decapoda). Philos Trans R Soc Lond B 345:373-393

Kellogg CW (1977) Coexistence in a hermit species ensemble. Biol Bull 153:133-144

Krol RM, Hawkins WE, Overstreet RM (1992) Reproductive components. In: Harrison FW (ed) Microscopic anatomy of invertebrates, Decapoda, Crustacea, Vol 10. WileyLiss, New York, NY, p 295-343

Manjón-Cabeza ME, García-Raso E (2000) Morphological reproductive aspects of males of Diogenes pugilator (Roux, 1829) (Crustacea, Decapoda, Anomura) from southern Spain. Sarsia 85:195-202

Mantelatto FL, Scelzo MA, Tudge CC (2009a) Morphological and morphometric appraisal of the spermatophore of the southern hermit crab Isocheles sawayai Forest and Saint Laurent, 1968 (Anomura: Diogenidae), with comments on gonopores in both sexes. Zool Anz 248:1-8

Mantelatto FL, Pardo LM, Pileggi LG, Felder DL (2009b) Taxonomic re-examination of the hermit crab species Pagurus forceps and Pagurus comptus (Decapoda: Paguridae) by molecular analysis. Zootaxa 2133:20-32

Matthews DC (1953) The development of the pedunculate spermatophore of a hermit crab, Dardanus asper (De Hann). Pac Sci 7:255-266

McLaughlin PA (1983) Internal anatomy. In: Mantel LH (ed) The biology of Crustacea, Vol 10. Academic Press, London, p 1-52

Melo GAS (1999) Manual de identificação dos Crustacea Decapoda do litoral Brasileiro: Anomura, Thalassinidea, Palinuridea, Astacidea. Editora Plêiade, São Paulo

Mouchet S (1931) Spermatophores des crustacés decápodes anomures et brachyoures et castration parasitaire chez quelques pagures. Bull Stn Oceanogr Salammbo 6:1-210

Provenzano AJ (1963) The glaucothoes of Petrochirus diogenes (L.) and two species of Dardanus (Decapoda: Diogenidae). Bull Mar Sci 13:242-261

Provenzano AJ (1968) The complete larval development of the West Indian hermit crab Petrochirus diogenes (L.) (Decapoda, Diogenidae) reared in the laboratory. Bull Mar Sci 18:143-181

Santos NM, Mantelatto FL (2011) Reproductive system of the male hermit crab Clibanarius sclopetarius: gonopore, spermatophore, and spermatozoal morphologies. Aquat Biol 12:271-280

Scelzo MA, Mantelatto FL, Tudge CC (2004) Spermatophore morphology of the endemic hermit crab Loxopagurus loxochelis (Anomura, Diogenidae) from the southwestern Atlantic-Brazil and Argentina. Invertebr Reprod Dev 46:1-9

Scelzo MA, Fantucci MZ, Mantelatto FL (2010) Spermatophore and gonopore morphology of the southwestern Atlantic hermit crab Pagurus exilis (Benedict, 1892) (Anomura, Paguridae). Zool Stud 49:421-433

Subramoniam T (1984) Spermatophore formation in two intertidal crabs Albunea symnista and Emerita asiatica (Decapoda: Anomura). Biol Bull 166:78-95

Subramoniam T (1991) Chemical composition of spermato- phores in decapod crustaceans. In: Bauer RT, Martin JW (eds) Crustacean sexual biology. Columbia University Press, New York, p 308-321

> Subramoniam T (1993) Spermatophores and sperm transfer in marine crustaceans. Adv Mar Biol 29:129-214

Tirelli T, Campantico E, Pessani D, Tudge C (2006) Description of the male reproductive apparatus of the hermit crab Calcinus tubularis (Decapoda: Anomura: Diogenidae). Crustac Res 6:13-21

> Tirelli T, Campantico E, Pessani D, Tudge C (2007) Reproductive biology of Mediterranean hermit crabs: male reproductive apparatus of Clibanarius erythropus (Decapoda, Anomura). J Crustac Biol 27:404-410

Tirelli T, Pessani D, Silvestro D, Tudge C (2008) Reproductive biology of Mediterranean hermit crabs: fine structure of spermatophores and spermatozoa of Diogenes pugilator (Decapoda: Anomura) and its bearing on a sperm phylogeny of Diogenidae. J Crustac Biol 28:534-542

Tudge CC (1991) Spermatophore diversity within and among the hermit crab families Coenobitidae, Diogenidae, and Paguridae (Paguroidea, Anomura, Decapoda). Biol Bull 181:238-247

> Tudge CC (1992) Comparative ultrastructure of hermit crab spermatozoa (Decapoda: Anomura: Paguroidea). J Crustac Biol 12:397-409

Tudge CC (1995) Ultrastructure and phylogeny of the spermatozoa of the infraorders Thalassinidea and Anomura (Decapoda, Crustacea). In: Jamieson BG, Ausio J, Justine JL (eds) Advances in spermatozoal phylogeny and taxonomy. Mem Mus Nat Hist Nat (Fr), p 251-263

Tudge CC (1996) Spermatophore morphology and spermatozoal ultrastructure of the recently described hermit crab, Strigopagurus boreonotus Forest, 1995 (Decapoda, Anomura, Diogenidae). Bull Mus Natl Hist Nat 4A 18: $547-555$

Tudge CC (1997) Phylogeny of the Anomura (Decapoda, Crustacea): spermatozoa and spermatophore morphological evidence. Contrib Zool 67:125-141

Tudge CC (1999a) Spermatophore morphology in the hermit crab families Paguridae and Parapaguridae (Paguroidea, Anomura, Decapoda). Invertebr Reprod Dev 35:203-214

Tudge CC (1999b) Ultrastructure of the spermatophore lateral ridge in hermit crabs (Decapoda, Anomura, Paguroidea). Crustaceana 72:77-84

Tudge CC (2009) Spermatozoal morphology and its bearing on decapod phylogeny. In: Martin JM, Crandall KA, Felder DL (eds) Decapod crustacean phylogenetics. CRC Press, New York, NY, p 101-119

Tudge C, Lemaitre R (2004) Studies of male sexual tubes in hermit crabs (Crustacea, Decapoda, Anomura, Paguroidea). I. Morphology of the sexual tube in Micropagurus acantholepis (Stimpson, 1858), with comments on function and evolution. J Morphol 259:106-118

Turra A, Branco JO, Souto FX (2002) Population biology of the hermit crab Petrochirus diogenes (Linnaeus) (Crustacea, Decapoda) in southern Brazil. Rev Bras Zool 19: 1043-1051

Watling L (1989) A classification system for crustacean setae based on the homology concept. In: Felgenhauer L, Watling L, Thistle AB (eds) Functional morphology of feeding and grooming in crustacea. Balkema, Rotterdam, p 15-16

Williams AB (1984) Shrimps, lobsters, and crabs of the Atlantic coast of the eastern United States, Maine to Florida. Smithsonian Institution Press, Washington, DC 